UDC 930.85

\title{
CONTEMPORARY TURKISH LANGUAGE: HISTORICAL-CULTURAL ASPECTS
}

\author{
Kseniya A. Milenkaya \\ State archive of Rostov region. Rostov-on-Don, Russian Federation \\ Marina I. Zhbannikova \\ Southern federal university. Rostov-on-Don, Russian Federation \\ science-almanac@mail.ru
}

The history of the cotemporary Turkish language development is considered, special attention is given to the question of Turkish alphabet formation. The instances of grammatical constructions are given for illustration of Turkish word-formation and word-inflection agglutinative peculiarities. It is marked the mutual penetration of foreign borrowings into Turkish language, as well as Turkisms into other languages, including the Russian language. It is mentioned the documents of the XVIII-XIX centuries, stored in the State Archives of the Rostov Region, which reflect examples of centuries-old relations with the Turkish neighbor. The basic part of the article is dedicated to the language reforms, conducted by Ataturk after the Turkish republic formation. A brief excursion into the history of the Turkish Historical Council and the Turkish Language Society creation was given, directions of their work, structure and leaders were characterized. The reforms results are given as the conclusion of the article.

Key words: Turkish language, Turkey, Ataturk, kemalist reforms. аспекты]

[Миленькая К.А., Жбанникова М.И. Современный турецкий язык: историко-культурные

Прослеживается история развития современного турецкого языка, особое внимание уделяется вопросу разработки турецкого алфавита. Для иллюстрации агглютинативных особенностей турецкого словообразования и словоизменения приводятся примеры грамматических конструкций. Авторы отмечают взаимное проникновение как иностранных заимствований в турецкий язык, так и тюркизмов в другие языки, в том числе и в русский. Упоминаются документы XVIII-XIX веков, хранящиеся в Государственном архиве Ростовской области, в которых отражены примеры вековых отношений с турецким соседом. Основная часть статьи посвящена языковым рефрормам, проводившимся Ататюрком после образования Турецкой Республики. Дан краткий экскурс в историю создания Турецкого исторического совета и Турецкого языкового общества, охарактеризованы направления их работы, структура и руководители. В заключение приводятся итоги реформ.

Ключевые слова. Турецкий язык, Турция, Ататюрк, кемалистские реформы.

Kseniya A. Milenkaya - leading archeograph. State archive of Rostov region. Rostov-on-Don, Russian Federation.

Marina I. Zhbannikova - lecturer of national History dpt. Institute of history and international relations of Southern federal university. Rostov-on-Don, Russian Federation.

Миленькая Ксения Анатольевна - заведующая отделом информации и публикации. Государственный архив Ростовской области. г. Ростов-на-Дону, Россия.

Жбанникова Марина Исматовна - ведущий археографр Государственного архива Ростовской области, научный сотрудник фрилиала Московский университет им. С.Ю. Витте. г. Ростове-наДону, Россия. 
Contemporary Turkey attracts large interest of Russian people, as by its health resorts, rather available for our country population, so also by cultural peculiarities of this east civilization. Interaction of Russia and Turkey counts more than one century. And these are not only wars or some political, diplomatic missions, these are trade, economics, customs, traditions, spiritual values exchange and cultural cross-fertilization of two civilizations. The documents of XVIII-XIX centuries, which are stored at the Rostov region public archives, testify about this. For instance, the copy of the military ataman A.I. llovaiskii from $24^{\text {th }}$ of January 1788 in the city Cossack villages about actions taking of Russian territory imperator defence from introduction and spread of contagious disease from Turkey [12], Imperator's decree from $22^{\text {nd }}$ of August 1860 about donation collection in favor of Christians, being persecuted in Turkey [10], the order from the $4^{\text {th }}$ of August 1861 about the Tatar village abolition in view of village citizens migration to Turkey [11]. The languages are not exception. Russian language has a lot of borrowings from Turkish, which are attractive for the linguists, historians, culturologists. For instance, watermelon, raisin, sofa, hood, egg-plant and many others [16]. But the Turkish language is attractive, not only for researchers, but also for usual inhabitants. Considering the historical aspect, all modern Turkic languages are divided into two branches: west and east hunnic. Oguzskaya group of languages, from which the modern Turkish language emerged, is referred to the first one.

The development of the Turkish language is divided into 4 periods: Old Turkic period (before XIII c A.D.), Middle Ages period (before XV c.), Ottoman period (XV-XIX centuries) and contemporary period. The Turkish language - agglutinative one. All word-formations and word-inflections in morphology occur with the help of various affixes joining (one, or more) to the word stem. For instance: derslerimizde "at our lessons" is composed from ders-ler-imiz-de, where ders - "lesson", - ler - plural number affix, imiz - affix of $2^{\text {nd }}$ person singular belonging (corresponds to the Russian possessive pronoun "our"), - de - affix Kalma (Bulunma) durumu (case of place and time), which answers the question nerede? - "where".

Vocalic harmony of vowels and consonants is the main feature of the Turkish language phonetic formation. Vocalic harmony of vowels (Büyük ünlü uyumu) is concluded in the fact that the first syllable vowel quality determines the vowels quality of the following syllables. But the given rule is not spread on the roots of foreign words, however, it acts with strict sequence under the various affixes (ekler) buildup for different lexical and grammatical word meanings expressions. The Turkish language consists as from originally Turkic words, so from borrowed - Armenian, Greek, Slavic, English, German, French words. The most part of borrowed words have Arabic and Persian origin. Arabic and Persian grammatical forms penetrated into the Turkish language through literature and religion; Persian language influenced on syntax.

The norms and rules of the modern Turkish language began to develop after the Kemalist revolution and republic formation. Till 1923 three styles existed under the influence of archaic letter forms on colloquial speech: 1. Kaba Türkçe (rough Turkish language), the language, spoken by the basic part of population, 2. Orta Türkçe (middle Turkish language), citizens' language. 3. Fasıh Türkçe, literature language till the middle of XIX century, mostly replete with foreign borrowings [15]. The Turkish Republic was formed in 1923 in the result of Ottoman Empire division after its deprivation in the World War I and national liberation struggle of the Turkish population. The Turkish republic founder Kemal', gave a great attention to culture, often speaking on this theme.

The Turkish institute was created on the $12^{\text {th }}$ of November 1924 after the year of Republic formation. Mekhmet Fuat Keprulu - statesman, philologist, historian and pub- 
licist, the founder of the Turkish literary study, became the first head of the institute [5]. $\mathrm{He}$ also was selected as the chairman of T.T.E. (Türk Tarih Encümeni) - the Turkish historical soviet [2]. Less part of the borrowings are present in the modern Turkish language in comparison with the Ottoman language. Differences between written and spoken language were significantly reduced. The Turkish language achieved the modern state thank to the language reforms, realized by Ataturk. The new era began in the Turkish language writing in XIX century: the lecturer of Kazan University and priest Ilminsky works for every Turkic language has its writing. Thus, Tatar and Kazak scientists played their role in the Turkish language life. The question of written language is argute in this time $[14$, p. 116].

The Ottoman Turkish, which was spoken in Ottoman Empire, was affected by different languages, and intrinsically, represented the "mixture" of Arabic, Persian and Turkish languages. The religious, juridical, scientific terms were borrowed from Arabic, terms from cultural and art sphere - from Persian, words, connected with economy and daily proceedings, were originally Turkish. Besides all these three languages refer to different language families: Turkish - to Altaic, Persian - to Indo-European, Arabic - to Semito-Hamitic. Thereat Arabic writing answered mainly purposes of Semito-Hamitic languages, as there are no vowels. It was not suitable for the Turkish language, even though that there are more letters in the Arabic alphabet, than sounds in the Turkish language. All these conditioned difficulties in language and writing study. Also the difficulties appeared under the higher education obtaining, as the education usually was realized in French language and transition to national language was complicated, especially in such sphere, as medicine [9]. Besides, some grammatical phenomena were borrowed: in grammar, issued in the beginning of the century, $40 \%$ of attention was paid to the Persian and Arabic grammar. For instance, the plural number was formed also according to Persian and Arabic samples, grammatical gender came from Arabic language, a definition and dependent member, as in Persian language was connected through the I letter (bab-i-ali - "high gate", under this both words - Arabic). Also, denomination of Porta Ottoman Empire government, accepted in history of diplomacy and international relations, appears to be French and Italian calque from bab-i-ali [1].

That is why the aim of reforms was concluded in creation the language, which at first was "more Turkish" and less "Islamic"; at second, modern, practical, uncomplicated; thirdly that with the help of it one could reduce the gap between intelligentzia and uneducated population layers, between citizens and country people [14, p. 119].

The first language reforms prerequisites began to appear at the second part of XIX century: in 1862 the theme of writing was raised by various political activists, but they did not offer the basic solutions of this problem. Besides, such reform was not possible to be conducted, as that time cultural policy direction could not allow this. Then, with the journalism development, in the second part of XIX writers, publishers and journalists acknowledged the requirement in new writing acceptance, for more readers, and also for simplification of Arabic and Persian constructions, which could be understood only by educated layers of population. After coming to power, Ataturk began to occupy himself with language questions. Ataturk, who had a military education, had two hobbies: linguistics and history. Ataturk took interest of linguistics since his youth, when he had an idea to refresh the language to return its "Turkishness". He believed that connection between language and feeling of national belonging is very important that the Turkish Language is one if the richest languages in the world and that the language should differ from the others for country to achieve the highest independence level. 
The most famous Ataturk's writing in Russia - his famous "Speech" (Nutuk), this piece of work is really unusual as in genre, so in content. This report was realized by him in 1927 at the II conference, of Nationally- Republican Party founded by him. The leader of new Turkey read "Speech" during six days. He outlined the whole history of struggle for the preservation and revival of his country in it, the most active participant of which was himself. "Speech" abounds in documents and can serve as a source for the history of Turkey. The language of "Speech", is full of specific clerical protocolar expressions, military terms of Arabic-Persian origin, often changing to pathos that composed considerable difficulties for translators. It is worth to mention that the original language of "Speech" is difficult for understanding by the contemporary generation of Turkish people that is why the renewed and simplified amendment of this writing is studied in Turkish educational institutions [13, p. 2].

Materials about language reforms were published in many newspapers and journals in 1923-1928. However it was not easy to assure intelligentzia: they spoke about that the old literature writings would be forgotten that the whole culture layer would disappear. The government began to issue agitation brochures to reduce amount of reform's opponents. The officially language revolution began in May 1928; the law of writing reform was issued in $3^{\text {rd }}$ of May 1928. National assembly members offered to gradually introduce a new alphabet - for 5 years. But Ataturk insisted on reducing this period to several months. He personally traveled to schools, gave lessons in rural areas, in remote villages, without stopping at anything. In some places he visited, the percentage of illiteracy strove to $100 \%$. Since January 1,1929 , it was forbidden to write in Arabic. On the 1 of September, 1929, the schools canceled the lessons of Arabic and Persian. A book by Sadri Maksudi Arsal (Sadretdin Nizametdinovich Maksudov - Russian and later Turkish lawyer, state and public figure) "For the Turkish language" (Sadri Maksudi Arsal "Türk Dili İçin" [4]), where the goals, which should be achieved by the reforms, are formulated. The author writes about the need to introduce new terms, new words that would improve the aesthetic side of the language and would emphasize the uniqueness of Turkish culture.

On July 12, 1932, the Turkish Linguistic Society "Türk Dil Kurumu" was founded. Ataturk wrote a work program for one night. Society work directions: "sözlük-terim" (lexicography - terminology), "dilbilgisi-sözdizimi" (grammar - word-formation), "etimoloji" (etymology), "filoloji-dilbilimi" (philology - linguistics). Only two members of the society had linguistic education in the initial group [8]. The first linguistic congress Birinci Dil Kurultayı was held three months later. The aim TDK - to make everything possible to open the real beauty of the Turkish language to the world was designated at the congress. The tasks were set for this: to compile the Turkish dictionary, the dictionary for the Turkish language dialects, the terms dictionary, to describe grammar, affixes, to write a history of language development, to compare it with Indo-European languages, Sumerian and Hittite languages, and to translate the works on Turkic studies, published in other countries into Turkish language [6]. In order to solve these problems, society was divided into parts: Dil Bilgisi Kolu (grammar sector), Terim Kolu (terminology sector), Yayın Kolu (publication sector), Derleme Kolu (words accumulation sector), Dil Bilimi ve Filolojikolu (linguistics and philology sector). Sector "Derleme Kolu" [14, p. 121] set to work immediately after the congress termination. Its goal was to find a substitute for all borrowings in the language, and thereby form a new modern language. There were three methods of substitution: 1) finding words in modern language, for example, in dialects; 2) finding words in ancient written monuments; 3) compilation of words from existing roots and affixes. "Hunting for words" began in October 1932. The governor of 
each region followed the work of the committee, which was responsible for the collection of words. 35000 of such words were recorded during the year. In addition, the scientists combed the dictionaries of other Turkic languages and more than 150 ancient texts and collected about 90,000 words. The thesaurus "Tarama Dergisi" was published by 1934, the year of the second linguistic congress [7]. Thus, for instance, the word kalem (pen), borrowed from Arabic, had synonyms yağuş, oryazgaç, çizgiç, kavrı, kamış. The word akıl (mind) had 26 equivalents, and the word hediye (gift) -77 . However, the accustomed word armağan is borrowed from Persian. Journalists wrote their articles in the familiar Ottoman language, then they referred them the special translator - ikameci, who with the help of thesaurus translated the article into after-reform language. But at the same time, "translators" working in different newspapers could use different synonyms of the same words. The second linguistic congress was gathered on August 18, 1934, at the Dolmabakhche Palace. Scientists from other countries also participated in this congress. It was decided to replace all borrowed terms with the Turkic roots terms at the Congress. In case this is not possible, take the western term, find its etymology (Latin, Greek, etc.) and form a term from the original word, adapting it to the Turkish sound. Another decision taken at the congress is to publish pocket Ottoman-Turkish and Turkish-Ottoman dictionaries. Thanks to these dictionaries, the words were fixed in the language: seçim (choice), önemli (important / importantly), uzman (expert), sonuç (result), etc. At the same time, the question was raised about how to get rid of the confusion that arose in the language because of the reform [3].

Later Ataturk concluded that the reform came to a standstill and the only one reasonable exit - not to fight with foreign words, which had no synonyms in the Turkish language, but to prove their Turkish etymology. Many neologisms were actually of Turkish origin and denoted what they denoted. For instance, altyap "infrastructure" instead of french. enfrastrüktür, çağrışım "association" instead of the Arab. tedai, kazı "excavation" instead of the Arab. hafriyat. These substitutions were really justified. But the language revolution caused a lot of incidents. Words formed from Turkic roots using Turkish affixes were sometimes incomprehensible. For example, instead of the Arabic mevhum "concept", the word kavram, derived from the verb kavramak "grab", was introduced. The word kavram existed in many areas of Anatolia and it meant "handful", that is, there was a coincidence of the neologism with the existing word. There were many words in the Ottoman language to describe the actions "to tell, to report, to announce, to give a hint", etc. Now modern Turks have to manage with the verbs anlatmak, söylemek and bildirmek with definitions for nuances designation. For instance, before there was a word "hint" - ima, now this meaning is transferred through the combinations of üstükapalısöylemek and dolaylıanlatmak. Thus, it is possible to single out the failures of the reform: 1) The gap between the educated and the uneducated layers did not decrease, but, on the contrary, increased; 2) many capacious words disappeared from the language, since Arabic or Persian words were withdrawn, and no worthy replacement was found; a modern Turk can face a situation where he simply does not have enough words, or there are words, but they are already outdated; 3) many substitutions were not of Turkish origin and therefore are not justified; 4) Turks under 50 years old cannot now read literature, written before the 20-30 years - in the period of Ottoman literature prosperity. Translations into the post-reform language are often unable to convey the beauty of the Ottoman literary language [14, p. 122-123.]. 


\section{Лumepamypa}

1. Babiali // http://www.beyaztarih.com/ansiklopedi/babiali

2. Buluç S.Türkiyat Enstitüsü.Türk Ansiklopedisi.Devlet Kitapları, C. XXXII, Ankara,1983, s. 312.

3. Karahan Leyla. Atatürk dönemi dil kurultaylarında/ TÜRKDÜNYASI.http://turkoloji.cu.edu.tr/ATATURK/arastirmalar/leyla_karahan_ataturk_donemi kurultay_turk_dunyasi.pdf

4. Maksudi S. Türk Dili İçin, Ankara: Türk Ocakları Yayınları. 1930.

5. Mehmet Fuat Koprulu // Режим URL: http://www.biyografi.info/kisi/mehmet-fuatkoprulu (дата обращения 31.08.2017)

6. Özdemir Orhan. Birinci Türk dili kurultayi bildirilerinde dil ve egemenlik ilişkisi. Turkish Studies - International Periodical For The Languages, Literature and History of Turkish or Turkic Volume 7/4, Fall 2012, p. 2511-2520, Ankara-Turkey

7. Tarama dergisi :OsmanlıcadanTürkçeye söz karşılıkları. Turk Dil Kurumu. Istanbul :Devlet Matbaası, 1934.

8. Türk dil kurumu. // http://tdk.gov.tr/index.php?option=com_content\&view=article\&id=77 (дата обращения 31.08.2017)

9. Zhbannikova M., Milenkaya K. Beginning of medicine history study in Turkey: education and publications // Научный альманах стран Причерноморья. 2017. № 1 (9).

10. Государственный архив Ростовской области (далее ГАРО). Ф. 226. Оп. 19. Д. 25. Л. 95.

11. ГАРО. Ф. 301. Оп. 8. Д. 587. Л. 234-2380б.

12. ГАРО. Ф. 338. Оп. 1. Д. 1015. Л. 21-21об.

13. Жевахов А. Ататюрк. Молодая гвардия, 2008.

14. Лингвострановедение второго иностранного языка (турецкий язык) / Г. Шенкал, Х. Ключук, Е. М. Фейтельберг. Красноярск, 2008.

15. Миленькая К.А. Турецкий язык как региональный компонент, используемый в высшем образовании на Юге России // Экономические, правовые, социально-политические и психологические проблемы развития современного общества. Материалы II межвузовской научно-практической конференции научно-педагогических работников, аспирантов, практических работников. 2016.

16. Шипова Е. Н. Словарь тюркизмов в русском языке. Алма-Ата, 1976

17. Petrova Yu.A. Language consciousness as the peculiarity of cultural differences// Научный альманах стран Причерноморья // Научный альманах стран Причерноморья. 2016. № 2.

\section{References}

1. Babiali // http://www.beyaztarih.com/ansiklopedi/babiali (date of resort 31.08.2017)

2. Buluç S.Türkiyat Enstitüsü.Türk Ansiklopedisi.Devlet Kitapları, C. XXXII, Ankara, 1983, p. 312.

3. Karahan Leyla. Atatürk dönemi dil kurultaylarında/ TÜRKDÜNYASI.http://turkoloji.cu.edu.tr/ATATURK/arastirmalar/leyla_karahan_ataturk_donemi kurultay_turk_dunyasi.pdf

4. Maksudi $\bar{S}$. $19 \overline{3} 0$. Türk Dili İçin, Ankara: Türk Ocakları Yayınları. 
5. Mehmet Fuat Koprulu // Regime URL: http://www.biyografi.info/kisi/mehmet-fuatkoprulu (date of resort 31.08.2017)

6. Özdemir Orhan. Birinci Türk dili kurultayi bildirilerinde dil ve egemenlik ilişkisi. Turkish Studies - International Periodical For The Languages, Literature and History of Turkish or Turkic Volume 7/4, Fall 2012, p. 2511-2520, Ankara-Turkey

7. Tarama dergisi :OsmanlıcadanTürkçeye söz karşılıkları. Turk Dil Kurumu. Istanbul :Devlet Matbaası, 1934.

8. Türk dil kurumu // http://tdk.gov.tr/index.php?option=com_content\&view=article\&id=77 (date of resort 31.08.2017)

9. Zhbannikova M., Milenkaya K. Beginning of medicine history study in Turkey: education and publications// Science almanac of Black sea region countries. 2017. No 1 (9).

10. The State Archives of Rostov region (further SARR). F. 226. Op. 19. D. 25. L. 95.

11. SARR. F. 301. Op. 8. D. 587. L. 234-238ob.

12. SARR. F. 338. Op. 1. D. 1015. L. 21-21ob.

13. Zhevakhov A. Ataturk. Young guard, 2008.

14. Linguistic Studies of the Second Foreign Language (Turkish language) / G. Shenkal, Kh. Klyuchuk, E. M. Feitelberg. Krasnoyarsk, 2008.

15. Milenkaya K.A. The Turkish language as regional component, using in higher education in the South of Russia // Economic, juridical, socially-political and psychological problems of the modern society development. The materials of the II interuniversity theoretical and practical conference of workers, postgraduates, practitioners. 2016.

16. Shipova E.N. Dictionary of turkisms in Russian. Alma-Ata, 1976.

17. Petrova Yu.A. Language consciousness as the peculiarity of cultural differences// Научный альманах стран Причерноморья // // Science almanac of Black Sea region countries . 2016. No 2 . 